\title{
Voting Alone: The Decline of Bodily Mass Communication and Public Sensationalism in Presidential Elections
}

Carolyn Marvin

University of Pennsylvania, cmarvin@asc.upenn.edu

Peter Simonson

Follow this and additional works at: https://repository.upenn.edu/asc_papers

Part of the Communication Commons

\section{Recommended Citation}

Marvin, C., \& Simonson, P. (2004). Voting Alone: The Decline of Bodily Mass Communication and Public Sensationalism in Presidential Elections. Communication and Critical/Cultural Studies, 1 (2), 127-150. https://doi.org/10.1080/

14791420410001685359

This paper is posted at ScholarlyCommons. https://repository.upenn.edu/asc_papers/634

For more information, please contact repository@pobox.upenn.edu. 


\title{
Voting Alone: The Decline of Bodily Mass Communication and Public Sensationalism in Presidential Elections
}

\begin{abstract}
The congregational crowd was a powerful mode of political communication in the nineteenth-century US until banished by the imposition of literate modes on popular electoral politics by Progressive reformers. We examine its major channels of expression, bodily mass communication and public sensationalism, within a framework of class-based struggle, observing that the practice of live bodily assembly created broad points of entry into political life, socialized the young, and successfully conveyed the importance of voting. A text-based normative model of the informed deliberative voter, we argue, offers too narrow a conception of participation compared to a more spaciously conceived democratic community.
\end{abstract}

\section{Keywords}

democracy, civic participation, bodily communication, class struggle, public assembly, voting

\section{Disciplines}

Communication | Social and Behavioral Sciences 


\title{
Voting Alone: The Decline of Bodily Mass Communication and Public Sensationalism in Presidential Elections
}

\author{
Carolyn Marvin \& Peter Simonson
}

\begin{abstract}
The congregational crowd was a powerful mode of political communication in the nineteenth-century US until banished by the imposition of literate modes on popular electoral politics by Progressive reformers. We examine its major channels of expression, bodily mass communication and public sensationalism, within a framework of classbased struggle, observing that the practice of live bodily assembly created broad points of entry into political life, socialized the young, and successfully conveyed the importance of voting. A text-based normative model of the informed deliberative voter, we argue, offers too narrow a conception of participation compared to a more spaciously conceived democratic community.

Keywords: Democracy; Civic Participation; Bodily Communication; Class Struggle; Public Assembly; Voting
\end{abstract}

The only weapon we have is our bodies.-Bayard Rustin

This essay seeks to retrieve a powerful mode of popular communication for a politics from which it is now, but has not always been, missing. We will use the term congregational communication to describe this instrumentality, which derives from deeply embedded social habits. As far back as the twelfth century, to congregate meant to make oneself a companion and accompany others in mingling, singing, fighting, or worshiping. Despite more contemporary associations with religious gatherings, congregations may amass as easily for rebellion as for worship, for lynching as for inauguration. Congregations are not defined by their moral achievements, but by the face-to-face circulation of a large number of people aware of their own collectivity.

As we mean the term, congregations are a species of crowd. We are interested in political crowds, or congregations, in US presidential campaigns during the late nineteenth and early twentieth centuries. Though congregational crowds are feared for their capacity to exercise physical force, this potential lies at the heart of their political efficacy. The capacity to control major sites of discourse physically and symbolically is fundamental to political change. ${ }^{1}$ Congregational crowds have often exercised power during the last two centuries, and still do. In terms of recent events only, Shia in Basra gathered by the hundreds of thousands to stake a claim to the religious and political future of Iraq after the fall of Saddam Hussein in 2003. Students in Tiananmen Square in 1989 pitted their bodies against a regime and mesmerized the world. More than one hundred thousand citizens pressed for civil rights for African Americans in the 1963 March on Washington, DC. Protesters disrupted the Democratic National Convention in Chicago in 1968. Moscow crowds helped protect the Russian parliament from a coup of its new democracy in 1991.

Powerful episodic crowds like these constitute one important form of congregational communication. Regularly occurring ritual assemblies are another. These once played a key role in US presidential elections, along with Independence Day the most important regularly occurring ritual occasions of the nation. Because participation in presidential elections is the privilege and right of all 
adult citizens, these recurring elections occupy a special place among US democratic rituals. By the end of the nineteenth century, however, congregational crowds in popular elections had become threatening to Progressive reformers and their allies. In the decades leading up to World War I, these reformers maneuvered to introduce literate modes that supplanted the unique communicative powers of electoral crowds, engineered their physical dispersal, and championed a notion of them as irrational and undemocratic.

Restrictions on popular crowds removed a significant means of forging and expressing what Robert Putnam calls "bridging" and "bonding" social capital among white working classes and immigrants, part of a more general elite effort to limit their participation in national politics. ${ }^{2}$ The delegitimatization of this popular communicative resource in favor of literacy-based forms weakened the challenge that less privileged classes could mount to a political system that had failed them in a rapidly industrializing economy. Our title refers to how reformers transformed Election Day into a ritual of "voting alone," a solitary act performed in private by literate electors abstracted from any witnessing or celebrating community. It plays on "bowling alone," Putnam's phrase for connecting the decline of associational sociability to falling rates of public participation in the twentieth century. In time, those for whom congregational crowds had been critical for mobilizing local allies and exerting local power became the least civically active participants of all.

Despite their continuing importance in social life, crowds remain largely unexamined in communication studies, ${ }^{3}$ perhaps because they are thought to lack an essential capacity for rational communication. This belief is a legacy of the period we examine, when reformers feared gatherings in public and pursued strategies to remove them from national politics. Though crowds now and then appear in the literature as receptive audiences, ${ }^{4}$ they rarely appear as agents of coherent messages. "Collective gatherings," by contrast, are often described as message-bearing entities. Émile Durkheim, for example, held a famously favorable view of the communicative efficacy of collective gatherings, asserting that society "cannot revitalize the awareness it has of itself unless it assembles." ${ }^{5}$

Crowds are especially suspect to those who point out that solidarity is not the same as rational decision-making. Nineteenth-century theories of the regressive psychology of crowds by Continental writers such as Le Bon, Sighele, and Tarde articulated elite hostility to forms of power manifest in unregulated popular assemblies. ${ }^{6}$ These theories influenced Progressive reformers in the US who were vigilant to the dangers of the "crowd mind."7 The history of crowds in US election rituals is thus tied to a larger struggle for power between popular and elite classes. We believe this struggle can fruitfully be mapped within a communicative framework of recurring class-based confrontations between bodily and textual styles of communication. The following discussion elaborates that framework and applies it to shifts in popular political communication at the end of the nineteenth century.

\section{Elite Texts and Massed Bodies}

Expressive bodily display is the preserve of the people, whose power and participation in society depend on the value of their bodies for the cultural muscle-work that society finds useful, especially manual labor and war. Textual expression is the preserve of those whose cultural power derives from educational and other textualizing credentials. ${ }^{8}$ In general, the bodies of those with the power to produce and use texts exert control over bodies that lack that power. The resulting story is never 
exclusively one of textual triumph, since texts in industrialized societies may elide and suppress the body but can never eliminate it.

This is not for lack of trying. Late nineteenth-century reformers criticized perambulatory outdoor gatherings and preferred the "public" to be seated indoors conversing and reading newspapers. In their view, literacy alone guaranteed virtuous civic behavior. It banished the menace of immediate action, the weapon of the crowd, by manipulating time and public visibility to frustrate congregational communication as an instrument of political participation. Most obviously, literate practice enforced temporal delays in exchanges among speakers and audiences. Authors could not be heckled or challenged during the writing process, and were long gone at the moment and site of published delivery. By this means, elite expression in essays and newspapers was able to remove itself physically from immediate popular engagement and criticism.

Elites also cultivated individual reputation and fame through civic written commentary. As a practical matter, the highest form of literate civic action vouchsafed to ordinary citizens was the secret written ballot-by comparison, a strikingly anonymous instrument. Counted ballots registered the aggregate democratic verdict, but concealed what had previously been open to inspection; namely, the identifiable political loyalties of live voters. These were barred from display at a moment when their force and weight would be importantly manifest to like-minded allies or determined opponents. Reformers argued that these and other literate constraints on popular participation prevented abuses by the crowd. We argue that congregational crowds were engaged in a species of nontextual communication worthy of analysis in its own right as a significant and distinctive democratic counterweight to elite power.

We will attend to two important components of nineteenth-century congregational communication that we call bodily mass communication and public sensationalism. Bodily mass communication was the immediate, live assembly of large groups in proximate, usually outdoor space less vulnerable than indoor spaces to extraneous control. It featured multiple bodies experiencing themselves as mutually present to one another. Collective scripted and unscripted expression offered a variety of opportunities to observe and embrace public roles in a highly theatrical setting. This was the mise-en-scène of public sensationalism, a dense, memorable sensory surround of immediate, publicly shared sights, sounds, smells, tastes, and touches. Public sensationalism heightened emotional arousal and channeled communicative intent. It marked off special occasions from ordinary events and drew those with unpolished cultural tastes and sensibilities into common enactments. Public sensationalism provided tools for rearranging public space and claiming it for the popular sphere.

We track the decline of congregational communication in nineteenth- and twentieth-century rituals of presidential campaigning by reconceptualizing recent accounts of campaign practice in US electoral history as skirmishes in a class-based, culturally fraught struggle between bodily and textual styles of communication. ${ }^{9}$ We argue that textualized messages displaced amassed, tangible bodies as the prevailing medium of ritual expression in presidential elections. In the late nineteenth and early twentieth centuries, electoral reforms emphasized the decorous, silent, and literate at the expense of the spectacular, raucous, and bodily. Live popular spectacle was drastically curtailed. Bodies no longer commingled in ways that integrated national politics with citizens' concrete lives. Collective participation was dislodged from the political center and appended to extra-local national campaigns that were deaf to the distinctive aesthetic, temporal, sensory, and social rhythms of local communities. 
We entertain scant nostalgia for nineteenth-century arrangements that barred women, blacks, Chinese, Native Americans and other groups from full political participation. These restrictions reflected a conservative popular politics structured by corporeal signifiers of race, gender, class, ethnicity, and regional style, and enforced through bodily intimidation that aggrandized white male political power. Important democratic elements nevertheless informed late nineteenth-century political rituals with broadband modes of entry for genteel and vulgar public tastes and multiple affirmations of the importance of ordinary people. These elements were removed by twentieth-century elites, particularly as they acquired momentum from industrialization and waves of European immigration. Since a good deal of democratic theorizing has overemphasized the cerebral ideal of the informed citizen without recognizing the somatic levels on which democratic political participation also occurs, these popular elements have not been fully appreciated. They are our concern here. For, as the popular body was dispersed and silenced at the turn of the twentieth century, elections became less compelling, large segments of the population removed themselves from the process, and the horizons of democratic possibility receded.

We focus on campaign practice from the Civil War to World War I, a period in which middle- and upper-class antipathy toward working-class citizens effectively narrowed the popular franchise. The struggle we describe between texts and bodies for control of presidential campaigns supports Alexander Keyssar's thesis that class antagonism was the chief obstacle to universal suffrage in the US during the nineteenth and twentieth centuries. ${ }^{10}$ Though Keyssar concedes that race, gender, and ethnicity strongly influence class position, he argues that class was the primary lens through which racial, gender, and ethnic divisions were understood and acted out. We argue that communicative style was an equally potent signifier of class position. In the period we examine, texts fought bodies and won. We begin by identifying traditional body-based components of presidential elections. Next, we discuss the unique ritual information that bodies communicate. We examine how bodily mass communication and public sensationalism conveyed the importance of elections, mounted civic appeals to less refined sensibilities, anointed individual participation with visible value, and dramatized popular power. We sketch the transformation to less popular, more textualized election rituals by the 1910s. Finally, we show how Americans continued to inhabit the disembodied political text during the 2000 presidential election.

\section{Bodily Participation and Popular Electoral Rituals}

The rise and fall of a distinctive popular political culture in the US is partly reflected in voting statistics from 1840 to 1920 . The last decades of the nineteenth century saw the highest voter turnouts in American electoral history. While about half of today's eligible voters cast ballots, 69 percent of eligible citizens voted on average for all presidential elections between 1840 and 1872 . For presidential elections from 1876 to 1900, that average was 77 percent. Participation in Northern states, separately considered, was higher still. From 1876 to 1900, 82 percent of Northerners cast ballots in presidential elections. Twelve different states registered turnouts above 90 percent in at least one presidential election during this period. These numbers dropped significantly in the first decades of the twentieth century. National turnout averaged 65 percent between 1900 and 1920, and 52 percent from 1920 to 1928. In the North during the same period, turnouts were 75 percent and 58 percent. ${ }^{11}$

Reported levels of electoral participation must be weighed against the fact that large segments of the population were prohibited from voting. Women, slaves, Native Americans, and minors remained 
disenfranchised throughout the nineteenth century. Free blacks voted only in a handful of states before the Civil War. Despite the enfranchisement of African Americans by the Fifteenth Amendment (1870), Jim Crow laws and social intimidation effectively reserved nineteenth-century voting to those who were white, male, and twenty-one. ${ }^{12}$ Little correlation existed between voting levels and socioeconomic status in the late nineteenth century. Generally speaking, working classes were as likely to vote as elites. This changed as elections became much less successful in drawing in the young and working classes, whose levels of participation declined steeply after $1900 .^{13}$

Attention to voting alone also fails to capture how campaigns and elections actually unfolded in nineteenth-century American life. Voting was only one facet of popular involvement in election rituals and must be considered within the broader sweep of popular power. This included mob violence against the abolitionist press and Reconstruction rioting by whites intent on removing federal force from the South following the Civil War. ${ }^{14}$ Of more concern to Northern propertied classes was the exercise of physical force by striking workers. Beginning with the Great Railroad Strike of 1877, the first nationwide labor action, US workers increasingly used their massed bodies to protest low wages, long hours, and unfair work rules. The number of strikes tripled in the mid-1880s, to about 1,500 in 1886, and remained high into the 1890s. Between 1875 and 1910, workers clashed with troops nearly 500 times. This period also saw some of the most infamous uprisings in US history, among them the Homestead steel workers' strike of 1892 and the Pullman strike of $1894 .{ }^{15}$ Against this background, popular crowds transformed late nineteenth-century presidential contests into charged public events that dramatized the force of assembled bodies and challenged an elite textualized order.

Presidential elections acquired a characteristic sequence and form in the post-Civil War era. In the spring of a presidential year, party activists assembled in ward, county, and state meetings to nominate local and state candidates and to select delegates for the national convention later that summer. By early summer, this participatory base had broadened to embrace political clubs formed for the duration of the election. These clubs organized local ratification ceremonies in which partisans shouted out assent and support for nominees to the national conventions. ${ }^{16}$ Local party cadres raised flagpoles that fluttered with partisan emblems and banners. They strove to cut down rivals' flagpoles in a spirited effort to show whose pole was longest.

Political clubs organized marching companies to perform elaborate drill maneuvers in partisan parades. Often held at night, these drew tens of thousands of marchers with brass bands, glee clubs, processions of wagons, and seas of kerosene torchlights. As Election Day neared, "monster rallies" attracted thousands more to large feasts and additional nighttime spectacle. ${ }^{17}$ Election Eve typically saw one last torchlight procession as parties mobilized their troops for the next day's battle. The climax of these popular rites was Election Day, an official holiday in many states. This ritual timeout from routine time was an all-day affair devoted to food, drink, and socializing. ${ }^{18}$ In contrast to today's lengthy and diffuse presidential campaigns, mid-nineteenth-century elections unfolded within a narrow interval that roughly coincided with the growing season, referencing rhythms of bodily work that had grounded centuries of settled collective life.

These activities made room for two groups excluded from voting, namely, white women and young white men. Beginning in 1840, Whigs encouraged women to attend political rallies $(10,000$ reportedly waved handkerchiefs at a Dayton, Ohio rally) at which speakers flattered them, and newspaper editors boasted about their presence. Democrats soon organized similar events for women, 
urging them to direct two-step flows of political communication to their voting menfolk. ${ }^{19}$ Women attended and marched in parades, in one case wearing sashes that proclaimed, "Whig Husbands or None." ${ }^{20}$ They decorated floats, hosted picnics and barbecues, lit their houses as their men passed by in torchlight processions, and extinguished the same light when political rivals approached. ${ }^{21}$ In some locales, they organized political clubs. After the Civil War, women presented home-sewn commemorative banners to party leaders at local mass meetings to kick off election campaigns. ${ }^{22}$

Boys, the largest disenfranchised group besides women, occupied a prized place of their own in electoral rituals. Adolescent white males recruited for marching companies often performed synchronized routines in public processions. ${ }^{23}$ New Jersey tradition called for boys to build Election Eve bonfires with confiscated boards, fences, and water barrels. ${ }^{24}$ Parades attracted young spectators of both sexes and socialized them to the larger political culture. ${ }^{25}$

Framing these activities as ritual adds a useful dimension to more conventional accounts of political participation. Though political activity may enlist ritual, ritual order is not political order, broadly understood as the distribution of power and resources. According to Roy Rappaport, ritual is a communicative form peculiarly designed to transmit certain kinds of information. It makes into res, or realizes, what cannot be accomplished by other means. Its distinctiveness is indexically tied to bodily presence. As Rappaport writes, "by performing a liturgical order the participants accept, and indicate to themselves and others that they accept, whatever is encoded by the canon of that order." ${ }^{26}$ What is ritually encoded is the message that the group exists, and that its members have concrete obligations to one another. Acceptance of this order is not manifest primarily as belief, an inward and private state, but acted out before observing others who reciprocate by signifying their own public commitments. Ritual indexically displays and morally enacts congregational existence by assembling bodies for mutual sensory contact and circulation. Their very presence in ritual settings publicly signals their willingness to participate in the group. ${ }^{27}$

Outdoor life in nineteenth-century towns was well suited for communities to experience themselves ritually. Though social-convivial campaign gatherings fell short of the inclusive equality of contemporary democratic ideals, they were unquestionably popular as rituals of unregulated public encounter. The looseness of popular crowds stood in marked contrast to European courtly traditions. Aristocratic rituals of theater, jousting, dancing, and religion conveyed what Habermas has called "representation[s] of publicness" 28 by closely regulating the location and movement of participants' bodies in roles reserved to the nobly born and specially elevated. Popular electoral rituals in the US presented few restrictions on gestures and permitted the comparatively free circulation of bodies. (By contrast, restraints imposed by nineteenth-century US elites on bodily expression among audiences for theater, opera, and symphony foreshadowed their domination of other aspects of twentieth-century culture, including political campaigns. ${ }^{29}$ ) Though access was far from total, social boundaries were also significantly more permeable in US election rituals.

Congregational communication in the popular sphere was never the rational-critical discussion of the Habermasian public sphere. The fertile fostering of body-based links through unregulated circulation created local traditions of participation in parades, rallies, flagpole-raising, drinking, feasting, voting and speech-making. Participation sometimes enacted celebratory unity, other times murderous confrontation. Though popular crowds could be convinced of their own charismatic morality in moments of public excitement, virtue was never the definer of the popular. If the bourgeois public 
sphere was constituted in textualized genteel discussion by a restrained and feminized "reading public," the popular sphere was constituted in fluid, unfettered circulation within a domain of public sensationalism. Its defining character was the muscle power lodged in amassed bodies boldly laying claim to public space. These displays threatened elites, who sometimes deployed domestic armies of uniformed soldiers and police, the visible antithesis of the unregulated crowd, to seize public space from freely moving masses.

\section{Sensing Public Life: Obvious Aspects of Campaign Ritual}

Bodily mass communication linked participants in festivals, feasting, fighting, rallies, and other public gatherings. It was enhanced by public sensationalism, an immediate surround of dense sensory cues that heightened collective experience and marked it as out of the ordinary. Public sensationalism constitutes the surface element of ritual, what Rappaport calls its "obvious aspects." Extraordinary, shared sensations drew attention to lived time and space by dramatizing and intensifying bodily experience to make it memorable. Public places filled with sights, sounds, smells, tastes, and touches drew community members to definable spaces. They focused collective attention. Public sensationalism signaled to ordinary people that elections were significant, and participation in them mattered.

Multiple modes of sensory stimulation courted a broad demographic swath. Popular songs with nonsense lyrics, stem-winding democratic oratory delivered to large crowds, nighttime seas of torchlight and flame, mass quantities of roasted meats, whiskey, hard cider, and beer appealed to less delicate political tastes. Fireworks, caged animals, balloon ascents, costumed adults and glee clubs offered up satisfying sensations for entire families. One observer understood the power of public sensationalism exactly. "They have discovered in this country the effects of the spectacular and the auricular," he wrote, "and they have applied it on a characteristically vast scale. You can disregard argument; you can ignore self-interest; you can forget country; you can even refuse a bribe. But you cannot fail to see and hear and to be struck well-nigh resistless by so imperious and masterful appeal to the senses of the body." 30

Election Day was a noisy affair. Amassed citizens, not mass-mediated commentators, made the public sounds. The democratic noises of bands, cannons and loud voices called the popular body to rites of civic regeneration. Polling places were beehives of voters boisterously hailing friends and acquaintances. ${ }^{31}$ From her front porch, a Missouri woman heard "hollering, screaming, cursing, and swearing that is constantly disturbing the peace." ${ }^{32}$ Amidst indecorous sounds of popular celebration, partisans gathered to out-sing and out-cheer their opponents. An observer noted "an endless flutter of fluttering flags, monstrous devices, a din of fife, trumpet and drum and the endless firing of light and heavy artillery." ${ }^{33}$ Finding his polling booth surrounded by Whigs bent on preventing their opponents from voting, a Democratic voter recalled, "Some halloed one thing and some another. Some imitated the Barking of Dogs and some the Roaring of Bulls, all making as much noise as they could." ${ }^{34}$

Elections featured special tastes. Election-day cakes baked by the women of the community were a favorite tradition, but public drink dominated the realm of popular taste. Liquor communicated and created festivity. Local candidates and party workers dispensed free alcohol, typically the greatest Election Day expense. ${ }^{35}$ In one city, Democrats brought voters to the polls in wagons stocked with whiskey barrels. Citizens also carried their own flasks and stood treat for drinks. A California voter 
reported having as many as 25 drinks in an hour with his friends, during which "many of us got pretty essentially tight." ${ }^{36}$ To some voters, drinking was the point of elections. A voter arrested in 1856 for disturbing the peace sang, "I'm no politician, nor ever shall be/ The job of my life is to go on a spree/ Whoever is president is all one to me/ While I can get gloriously corned." ${ }^{37}$ Repeated Election Day efforts to regulate New Jersey saloons during the 1880 s were mostly futile. ${ }^{38}$

Liquor facilitated rituals of public touch-from handshakes and other amicable connecting rites to physical intimidation. A Mississippian remarked that men gathered "for the triple purpose of voting, spreeing and lastly for the peculiar pleasure of witnessing the beginning-aye, 'The Opening of the Fall Fighting Campaign.' "39 The very possibility of violence heightened ritual drama and interest. Partisan toughs, "b'hoys" and "shoulder strikers" staged real and sham fights to keep timid opponents from the polls. ${ }^{40}$ Election Day mobs armed with rocks, brickbats, guns and knives caused significant bloodletting and accounted for at least 89 deaths between 1828 and $1861 .{ }^{41}$

Contemporary "campaigns" are pale echoes of the pugilistic rehearsals that dominated popular elections from the 1850 s to 1890 s. Agonistic masculine drama representing the force of the popular body coursed through nineteenth-century political rhetoric. Electoral sensations frequently suggested preparation for war, and parties understood their work as mobilizing every eligible voter. Deploying slogans such as "Falter not before the enemy," each side marshaled troops to battle the opposition. Political clubs formed marching orders with "captains" and "lieutenants." These orders paraded in every style of uniform from kepis and oilskin capes to elaborate military dress accessorized with leather spats, belt, gloves, and dress headgear. Brandishing torchlights that resembled rifles, political foot soldiers executed intricate drills to crisp military commands. Parades mimicked battlefields with gun and cannon fire, fireworks, skyrockets, roman candles spewing from "volcano wagons," and the smell of sulfur and smoke. Accompanied by brass bands, martial songs issued from the bellowing voices of marching men and officers on horseback. ${ }^{42}$ On such occasions, young, especially working-class men, were ritual actors in barely restrained displays of masculine violence intended to thrill and intimidate spectators in the streets. Just as royal processions symbolized and displayed political power backed by force, pageants of marching men presented themselves as the democratic sovereign whose formidable strength likewise could be mobilized. When violence did erupt from volatile shifts of crowd mood, or exerted itself against group obstacles or other persons, it enacted tactile communication that conveyed popular power in the most direct terms. When this era ended after World War I, a powerful avenue of body-based political expression was effectively closed.

Voting provided important shared sensations of its own. Until the 1890s, exercising the franchise was a communally observed, public act. Visually distinct ballots printed and distributed by political parties told onlookers what ticket a voter had deposited. ${ }^{43}$ Openly voting a straight ticket was customary, though some electors created bobtail tickets by tearing names off the ballot, or vestpocket votes by hiding their tickets all the way up to the ballot box. ${ }^{44}$ For the most part, voting the ticket was a semi-public display of party affiliation frequently met with offers of solidarity in the coin of jobs or friendships. ${ }^{45}$ These gestures grounded open communication before peers in networks of public opinion that allowed individuals to communicate particularistic contributions to the constitution of the body politic.

Public balloting was accompanied by rituals of reciprocity in which electors received direct signs that individual participation mattered. Though charges of "vote buying" were freely tossed around in 
the nineteenth century, the exact meaning of this term remains in dispute. Small monetary payments and in-kind treating were common on election days. ${ }^{46}$ In some towns, "floaters" did sell their votes to the highest bidder. More often, cash and in-kind transactions such as drink buying were festive public rewards for party work and loyalty. ${ }^{47}$ Reciprocity was sometimes supplemented by coercion. On Election Day, party emissaries cajoled, browbeat, and transported electors to the polls. ${ }^{48}$ Such demonstrations rendered visibly concrete each elector's connection to the popular democratic body and made it hard to doubt the significance of voting.

Some historians have questioned the depth and breadth of popular commitment behind such lavish campaign activity. Altschuler and Blumin suggest that presidential elections were high points in a political culture that faded from view in off-year elections, and that nineteenth-century Americans were emotionally disengaged from public life..$^{49}$ In this light, rallies and parades appear less as spontaneous expression than party artifice, and as spectacles of entertainment more than engaged politics. They argue that candidates were designated less by popular choice than by political insiders who engineered electoral outcomes with vote-buying strategies and get-out the-vote schemes. Finally, they suggest that politics was widely regarded with cynicism and doubt.

These observations can be read differently by focusing on how rituals work. That popular politics had periods of low intensity, with off-year elections generating less hoopla and people quickly resuming normal lives after Election Day, ${ }^{50}$ suggests that presidential elections took place within a ritually distinct interval able to attract high levels of public interest. It must also be acknowledged that little large-scale democratic participation of any kind passes the test of collective spontaneity. Ritual nearly always depends on deliberate organizing efforts that count as public evidence for it instead of detracting from its value. Finally, claims that nineteenth-century campaigns were entertainment rather than politics generate a false dichotomy based on a narrow view of politics as serious business devoted to intellect and not sentiment. Popular politics drew in participants from many different realms by finding ways to be compelling to all of them. This heterogeneity was a ritual strength, not a shortcoming.

Bodily mass communication provided modes of entry into public life for sensibilities unmoved by the niceties of political discussion and unencumbered by copious political information. It assembled the people for the purpose of reaffirming themselves in all political circumstances. Witnessing, sensing, and acting together created a res publica of mutual solidarity among bodies singing, shouting, swaying, or marching together, occupying shared space, collectively embracing and repelling other bodies. Such activity rendered public opinion concrete and formidable. The body politic was viscerally present and passionately apprehended. Shared perceptions, social connections, and massed bodily force constituted the essential resources of popular communication and power. As strikes and other forms of labor unrest drew on and absorbed popular election experiences, they magnified the concerns of those who distrusted popular will and sentiment as base, and more, as hostile to elite interests.

\section{Textualizing Popular Ritual}

For most of the nineteenth century, popular elections featured the visual excess of too many bodies to take in at a glance, the aural excess of sounds of war, the tactile excess of male bodies primed with alcohol and partisan emotion, and the gustatory excess of roasted animals consumed en masse. Such spectacles were the antithesis of bourgeois refinement. They offended elites and middling sorts focused 
on more delicate indoor activities of parlor and study, including discussion, silent reading, intimate gatherings of family and friends, and solitary prayer. ${ }^{51}$ In the $1880 \mathrm{~s}$, Newark Republicans bristled at "the 'push' and 'squeeze' and sometimes dirty contact of a crowded polling place." ${ }^{12}$ They reflected the patrician sentiments of those who preferred to distance their bodies from a popular politics they regarded as impure.

Between the 1880s and World War I, reformers made stringent efforts to purge presidential elections of public sensationalism and to suppress bodily mass com munication. By purifying these popular aspects of presidential election ritual, they also transformed its meaning. Citizens were less likely to enact electoral ritual in democratic masses, more likely to encounter mass mediated texts detached from collective contexts. Spectacular, raucous bodily public idioms no longer staked a familiar, structured claim on popular politics. Massed bodies, locally rooted and dramatically unpredictable, gave way to the newly mobile, singular bodies of presidential candidates, whose remotely mediated images were fixed in standardized forms. Dispersed and driven indoors, the democratic mass became less visible, audible and real. Eviscerated and textualized, it gradually became the abstract and imagined political entity it is today.

Textualized voting disenfranchised those bodies most feared by elites and the middling classes. In the fifty years after 1860, voter registration laws enforced through new regimes of the written word demobilized large numbers of Northern immigrant working classes, Southern blacks and poor whites. ${ }^{53}$ Beginning in the late 1880 s, seventeen states imposed literacy tests for voting. In the South, Jim Crow laws bypassed the Fifteenth Amendment's (1870) enfranchisement of African Americans. ${ }^{54}$ Between 1900 and 1926, eleven states repealed laws enfranchising aliens who publicly swore their intentions to become citizens. By 1928, no alien in any state had the right to vote for a candidate for any office for the first time in a century. ${ }^{55}$ Bodily oaths were invalidated, and immigrants were required to bring citizenship papers to the polls. Nine Northern states instituted literacy tests before $1920 .{ }^{56}$ Echoing the views of many Progressive era reformers, the Newark Evening News wrote in 1900 that "the man who can neither read nor write demonstrates a lack of intelligence or ambition that should disqualify him from exercising the highest prerogative of American citizenship." 57

As legislative reforms swept the country in the late 1880 s, the ballot was also purified. Thirtyeight states passed new ballot laws between 1888 and $1892 .{ }^{58}$ Many of them mandated uniform ballots printed on standard paper on which only the names of duly certified candidates could appear. Ballots often had to be authoritatively stamped and distributed by "sworn public officials," not "paid political workers," as the New York Ballot Reform League framed the alternatives. ${ }^{59}$ Buffer zones were drawn around polling places to exclude onlookers, and voters were required by law to shield their ballots from public gaze. ${ }^{60}$ Private literate effort replaced public performance and display as voting became a matter of decoding lists of printed names and properly marking ballots.

Secret balloting significantly changed the meaning of voting. The franchise had been a public act of political affiliation undertaken in the presence of others who were spectators, judges, allies, and interlocutors in the constitution of a local public opinion that could not be ignored or denied. Secret balloting silenced this communicative dimension. Voting no longer "obviously" constituted or reflected local bonds. The significance of one anonymous, socially ungrounded vote for president, among millions, now seemed far from obvious. Any single vote seemed only to ratify distant state power. Exchanges of money had likewise recognized social and political debts incurred. In the reform era, states strove to 
keep any money from changing hands. In 1906, the State of New Jersey hired detectives to police "vote buying" and enforced anti-liquor laws with new vigor. ${ }^{61}$

Reformers were also bent on purging many of the sights and sounds that had communicated the distinctiveness of Election Day. Bonfires were classified as safety hazards. Election-night fireworks, horns, and sirens were banned as public nuisances. ${ }^{62}$ Previously rowdy city wards were now "devoid of any of the real old time excitement," the Atlantic City Evening Union wrote. ${ }^{63}$ Observers called elections "listless," "dull," and "exceedingly quiet," and remarked on the "astonishing lethargy" of the population. ${ }^{64}$ Without tangible signs that their votes mattered or obvious sensations to tell them this day was different, citizens fell back on abstract notions of doing their civic duty. Unsurprisingly, voter turnout dropped: nationally, from a 77 percent average between 1876 and 1900, to 65 percent from 1900 to 1920, and 52 percent from 1920 to 1928; in the North, from over 82 percent to 75 percent and 58 percent for the same periods. ${ }^{65}$

What was true of Election Day was true of the whole campaign. The spectacular popular campaign was fast receding into memory by the first decade of the twentieth century. ${ }^{66}$ In the countryside, all-day rallies with parades and speeches declined after 1900 . Urban communities followed suit. Torchlight parades and daytime processions were all but gone by 1908. Loyal partisans no longer illuminated homes or businesses. Parties seldom hired brass bands or assembled glee clubs. Election bets with public payoffs, once common, became an oddity. The campaign clubs that formed the backbone of organized popular politics dwindled after the 1890s. Uniformed marching companies were virtually extinct by 1912. The Newark Star wrote in 1908, "The political value of these demonstrations have [sic] been seriously questioned by campaign managers who pointed to their excessive cost and argued that the money expended could be put to better uses - notably, printed matter, mailings, and advertising. ${ }^{67}$ In effect, the parties redirected money and energy from the popular mass to elitecontrolled mass communication.

Popular bodies deferred to two kinds of textual elites. One championed a purified, disembodied politics of individual conscience and dispassionate principle disembedded from partisan spectacles filled with rich emotion and sensory excess. It favored informational texts to educate and discipline the masses. A second elite deployed new textual technologies of advertising and public relations to compete with public sensationalism by packaging presidential campaigns with pithy slogans and mechanically reproduced likenesses. Presidential campaigning gradually shifted from multiple encounters among ordinary citizens to remote visions of the elevated singular bodies of candidates. Regular, raucous political participation retreated to indoor, intimate, and private social space. Elites contrasted the orderly literate habits of an abstract public to the muscular unpredictability of the crowd. Deliberative public opinion, a new entity, was celebrated as a benefit to all. In actuality, such equality was more abstract than real, since deliberative resources found their greatest purchase among the educated. Through secret balloting and new restrictions on electoral eligibility, literate elites stripped political agency from assembled, socially linked popular bodies. The bodily ground of election ritual shifted from congregational masses rooted in concrete community relationships to the singular, abstractly social bodies of newly mobile presidential candidates.

Two new political styles emerged: educational and advertised politics. ${ }^{68}$ One modeled middlebrow education; the other, advertising and public relations. Both deployed literate modes in which popular bodily idioms found little place. Both favored textual distribution to distant audiences 
over locally performed and evaluated bodily gestures. Following the Civil War, elite reformers pursued the educational style in national campaigns of the printed word. ${ }^{69}$ Mugwumps early yoked the ideal of informed citizenship to anti-partisan independent-mindedness, but both major parties adopted this notion with a vengeance by 1892 . Beginning in the 1870 s, party "information bureaus" printed millions of documents on tariffs, free silver, and other issues. Educational campaigns sought "less noise and more solid work." They aimed "to supply voters with the 'right kind' of literature." ${ }^{70}$ Printed party platforms likewise increased in length and detail. No more than a page and a half in the $1880 \mathrm{~s}$, by the 1910s they routinely ran four to eight pages. Addressed to solitary readers, their arena was private and domestic; their tone was earnest, favoring sobriety and conscience over sensationalism. "This is not a campaign of noise and dazzle," observed the Cleveland Plain Dealer of the 1892 race, "but of reading, of thinking and of work." 71 Printed platforms seemed to make bodily mass communication unnecessary. Where information came directly from the national organization, there was little need to work out political views in concert with others, a socially unpredictable process beyond the supervision of elites and potentially threatening to them.

Changes in journalism went hand in hand with educational politics. Though media had always been part of political campaigns, the relative balance between bodies and texts now shifted disproportionately towards the latter. Nineteenth-century newspapers had spoken for party organizations whose funds often supported them. As urban audiences increased in size, literacy, and affluence during the 1870s and 1880s, big-city newspapers cultivated new readers and constructed new relationships to them. Editors trumpeted a new kind of journalism that served the public good by remaining independent of party. Reporters, increasingly "educated men," sounded the virtues of deliberative politics and "accurate, factual" news, replacing partisan drama and loyalty with impartial, distanced views of the facts. Joseph Pulitzer and William Randolph Hearst wooed the jilted popular body for a new kind of urban mass press that appealed to sensory experience with lavish illustrations, banner headlines, color printing, stunts and crusades, and lurid stories of crime and sex.

Both the independent and mass press stigmatized partisan subjectivity. The independent press championed professional textual expertise as a reflection of lofty, high-minded devotion to education and independence from political partisanship. Though it avoided explicit class appeals, this vision was in truth class-specific, offering a self-absorbed and narrowed politics that most appealed to middle and upper classes. The mass press engaged political stories as gossip rather than public affairs, and derided a politics of ideas in favor of a politics of personalities and private lives. Journalism thus colluded in a textually driven split between thought and feeling, associating good politics with dry civic pedagogy, and feeling and emotion with low prejudice. If the independent press made politics too complicated for working class readers, the mass press trivialized it. Forced to compete with independent and sensational styles, the party press abandoned its traditional role of creating a politically comprehensible world for readers in partisan terms while shifting its economic base from partisan expressions of political preferences to advertising.

Advertised politics was the second textualized mode deployed in presidential campaigning. ${ }^{72}$ Where educational politics emphasized policy and principle, advertised politics presented presidential candidates as personalities. Advertised politics circulated pithy fragments of discourse as "advance copy," rendering actual bodily utterance nearly superfluous. Whereas educational politics relied on traditional technologies of plate matter and pamphlets and elite rules of discourse, advertised politics seized on representational modes associated with emerging technologies of mass communication. Its 
tools were advertising, public relations, mass-circulation daily newspapers, half-tone engravings, motion pictures, and later, radio and television. All these created the candidate as a textualized presence detached from local and community relations of the sort dramatized and enacted in spectacular partisan display. Though not fully deployed until the 1916 campaign, the advertised style had germinated for two decades in the parties' new national "publicity bureaus" where the inventors of modern public relations, Ivy Lee, George F. Parker, and George Creel, had all apprenticed. Its practitioners angled strategically for coverage by purchasing full-page ads from independent-minded print media in steady retreat from traditional partisan loyalties. They helped direct money toward textual and advertising elites and away from ordinary voters and body-based partisan spectacle.

Candidate bodies moved definitively into the public arena during the bitterly fought 1896 campaign in which both presidential contenders actively campaigned for the first time. In the semipublic space of his Ohio front yard, William McKinley displayed himself almost daily to journalists and supporters. William Jennings Bryan traveled to twenty-nine states in a strategy calculated to capture coverage in newspapers, most of which were editorially opposed to Democrats. ${ }^{73}$ Popular bodies receded from view in presidential campaigns to be replaced by proliferating images of the bodies of candidates. These were readily abstracted into newspaper and campaign texts that aimed at dispersed national audiences and bypassed particularistic local webs of class and social relations. Along with stickers and posters inscribed with trademark slogans like "Full Dinner Pail" and "Poverty or Prosperity," Republicans distributed millions of mechanically reproduced images of McKinley. Theodore Roosevelt famously observed that Republican chairman Mark Hanna had "advertised McKinley as if he were a patent medicine!"74

While street protests by suffragists in the 1910s demonstrated the ongoing power of amassed bodies to press for democratic reforms, the popular body was no longer a regular player in American political life by the time women gained the vote in $1920 .{ }^{75}$ Ballot reform and textualized campaigns of education and advertising had helped engineer the end of the democratic crowd as the bodily ground of election ritual. As locally produced campaign spectacles withered, and Election Day revelry died down, campaign crowds gathered mostly when presidential candidates came to town. Where outdoor assemblies once had given form to the rhythms and relations of local political life, distant party elites supervised the schedules of whistle-stop gatherings that displayed little interest in homegrown traditions.

As popular bodies migrated to alternative rites of sport, religion, and mass entertainments, collective attention shifted from political and labor spheres to consumption, games, and spirituality. By the 1890s, professional baseball and college football gathered large crowds in less open, less perambulatory spaces that were increasingly yoked to commercialism. Dwight Moody and Billy Sunday updated an American tradition of mass religious revivals, in which shouting, swaying bodies were restrained by Protestant morals, and bourgeois manners disciplined the rougher side of the electoral congregation. New amusement parks furnished new, mechanically manufactured bodily sensations and electrified some of the nocturnal excitement and social fertility of torchlight electoral parades. Civic sympathies sounded a minor chord in these commercially pitched spectacles of bodily mass communication.

With the eclipse of body-based electoral communication, US citizens had lost a unique way of experiencing themselves as publicly assembled congregations engaged in civic rituals of consequence. 
As the electoral crowd waned, so did its political power. Gone were recurring exhibitions of muscular force in the disciplined, latent violence of the march and the unrestrained violence of the mob. Bodily mass communication had been a powerful magnet for people of less refined tastes and less discursive dispositions. This was especially true of the young and working classes, two groups dramatically disengaged from contemporary elections. As the drama and pageantry of voting were textualized, the thinner sensationalism of the mediated word supplanted live electoral sensations. Public opinion was no longer felt and experienced concretely, but simulated in aggregated votes and statistically drawn polls. In an earlier era, the congregational crowd had informed itself of the collective and individual importance of its members. In spite of being socially partial in their constitution, the popular electoral rituals of that era compare favorably in inclusiveness and democratic procedure to contemporary rituals in which candidates and elite commentators occupy the symbolic center; wealthy, textually certified elites pull the strings, and the public is concealed and dispersed in private and semi-private indoor spaces.

Conspicuous investments of local energy and treasure in nineteenth-century electoral contests displayed and strengthened the alluvial, recursive sociability of community life. Criss-crossing social and political bonds created sturdy networks through which local power flowed. Texts as a contemporary political mode, by contrast, are largely indifferent to surplus social value created by bodily mass communication, the better to flow unimpeded through channels directed at those whose sole value to political elites is the mobilizeability of their votes. Throughout the twentieth century, dispersed communities became increasingly tethered to a national center by centralized political communication, civic education, and mass media. These textual forms were able to bypass, and thus helped to atrophy, the political and social links binding local citizens to one another. Streamlined political communication also narrowed the messages that passed between ordinary citizens and political elites on terms specified by the latter. The socially thinnest dimension of voting, mere number, projected a politics divorced from bodies. Deprived of that power, they offered no barrier to centralizing national elites and withered as a political force.

\section{The 2000 Presidential Election: Voting Alone}

The popular body was a significant, though unacknowledged, player in the most famous controversy in recent US presidential election history, the 2000 race between George W. Bush and Al Gore. A perilous moment of that contest came when a menacing mob of partisans intimidated Miami-Dade County election commissioners debating a vote recount. During the time the vote was in dispute, street crowds asserted themselves across Florida, at the Texas governor's mansion in Austin and at the vicepresidential residence in Washington, DC. This unaccustomed embodiment of strong partisan sentiment, a throwback to the lively nineteenth-century electoral crowd, was widely deplored as menacing and contrived.

For a moment, it seemed that bodies might decide the election through hand recounts locally negotiated, but that moment passed. The US Supreme Court ruled that bodies must remove themselves from proximity to the ballots to prevent further contamination. As it had in the early twentieth century, the historical strength of the reforming impulse kept bodies and texts at a purifying distance from one another in this most important of national rituals. A review of the disputed counties by the US Civil Rights Commission showed that ballots cast by African Americans - the most suspect stratum of bodies 
in the national electoral imagination-were ten times more likely to be rejected by textual rules for valid ballots than those cast by white voters. ${ }^{76}$ Cast in textualized form, tribal exclusivity remained the order of the day.

Beyond the extraordinary events in Florida, which bodies merely threatened to unravel, the national election presented the usual story of textual triumph and bodily disengagement. In an election officially too close to call, voter turnout was 51 percent, in line with a long-term decline over the twentieth century. Though pundits claimed the lesson of Florida was the sanctity and power of individual votes, unguarded remarks occasionally belied these sentiments. In a humorous aside, a New York Times columnist betrayed an elite disposition to value individual voters mostly in the abstract: "We treasure the idea that any one individual's ballot could decide an election. But watching the interviews with some of the men and women on the street in Florida, you can't help think, oh, Lord, not that one."77

Ordinary voters in the 2000 elections knew they were not consequential players. Handfuls of votes rarely determine presidential elections, and Florida was more anomaly than lesson. Modern elections mostly range the elite forces of the advertised style of politics against those of the educational style, leaving most of the country out of the loop. In the wake of Florida, some reformers championed textual remedies to correct ballot irregularities with voting machines designed to minimize bodily contact with the ballot. Others proposed to remove the body altogether by standardizing local election procedures and automating vote counts entirely. All ignored the continuing disengagement of popular bodies from the political process. The passionately engaged popular body so feared by nineteenthcentury political elites thus stands in sharp contrast to the popular body of today. This latter body elicits neither fear nor respect, since it is nowhere concretely to be found. Mediated punditry invokes it largely in the breach. It is remarked on dismissively, as in the words of the Times columnist above; abstractly, in what George W. Bush called "that big swath of red on the map" of televised election returns; ${ }^{78}$ and now and then in reverent genuflection to the deliberative ideal that has put an end to it.

In the election of 2000, the candidates' bodies were as mobile as ever, traveling in an attempt to generate political spectacle and popular audiences. Sometimes they were successful; often they were not. The alienation of everyday bodies was reflected in this account of the presidential campaign's final week:

For a moment on Monday morning, Sandra Shipley thought she might head over to Portland Community College to see the man she prefers to be the next president of the United States, Vice President Al Gore. Don Hagar thought, briefly, of attending an afternoon rally at Memorial Coliseum for his man, Gov. George W. Bush. Instead, Ms. Shipley shopped for shoes, and Mr. Hagar went for a 10-mile run. "He's not a very exciting speaker," Ms. Shipley, 32, a part-time student, said of Mr. Gore. "I mean, as a Democrat, I'm voting for him. That should be enough." Mr. Hagar, 42 , a sales manager for a computer parts company, was hardly more apologetic. "The way they promoted the event, I knew they wouldn't miss me," he said. ${ }^{79}$

These citizens saw their bodies as superfluous to collective gatherings that once lay at the heart of campaign ritual. In response, the candidates offered nothing sensational to engage face-to-face audiences. These voters expressed their apathy by choosing alternative body-focused activities, pampering the body in one case, disciplining it in the other. Both voiced the broad piety that only voting is a significant political act. 
On important occasions when the candidates were brought before the masses, the masses were instructed to behave themselves. Normative talk around the nationally televised presidential debates presumed an electorate of informed, independent-minded citizens whose bodies could not be trusted to remain silent and decorous. A letter to the editor of the New York Times urged the evacuation of popular bodies from the deliberative field of rational, unbiased observation.

Now that the presidential debate format has been settled ... there is one detail that is necessary for these debates to be fair: the local audience should absolutely not be shown on the air. If it were, millions of TV viewers would be distracted and possibly biased by the reactions of that audience, at the risk of defeating the entire purpose of these debates: to give the country the opportunity to view and evaluate the candidates being themselves, pure and simple. ${ }^{80}$

Popular bodies threatened to attach the presidential candidates to "local" audiences of supporters and detractors instead of allowing them to stand, godly, alone.

The elite journalist selected to moderate three nationally televised debates forbade crowd participation at the first of them and clamped strict limits on partisan enthusiasm:

There's a small audience in the hall tonight. They are not here to participate, only to listen. I have asked and they have agreed to remain silent for the next 90 minutes except for right now when they will applaud as we welcome the two candidates. ${ }^{81}$

Except as silent spectators, popular bodies were banished from the debates. The small and grudging exhibition of feeling allowed them was closely monitored. They were still more forcefully admonished before the second debate:

The audience participants ... shall not ask follow-up questions or otherwise participate in the extended discussion. And the questioner's microphone will be turned off after he or she completes asking the question. ${ }^{82}$

Thus were onlookers barred from affective displays and permitted only the most truncated participation in the much-touted rational discussion of the issues.

When, on another occasion, a broadcast network organized focus groups meant to provide deliberative civic simulacra for viewers, participants were unsure how to act. These citizen "undecideds," unaccustomed to having their bodies publicly included in the campaign, fell back on the ritual props of the cerebral voter:

The participants, jittery at first, clutched pens and pads and took pages and pages of notes during the debate. As the cameras prepared to beam them to the nation, they fell utterly silent. ${ }^{83}$

There were faint echoes of the lost customs of nineteenth-century politics. Before their public performance, the participants "munched on a buffet dinner of chicken and meatballs" and got their "marching orders" from a CNN executive. For this well-fed statistical sample, "marching" meant sitting still for turn-taking parlor conversation among others with whom they shared mainly a lack of conviction about the candidates. By such means, tentative, engineered talk has supplanted mass bodily noise as the characteristic sound of modern elections. The embodied electoral crowd has largely ceased to be visible to itself or anyone else. Cut off from itself as the body politic, it has become the logical product of the modern election process - the socially detached, apathetic class of "undecideds." Unanchored in a materially obvious political life, it is sporadic, uninterested, and free-floating. 
Meanwhile, the textual armies of advertised politics grew richer from political business. An expert array of journalists, pollsters, media buyers, telemarketers, ad agencies, and political consultants deployed arsenals of computer databases, direct mail, websites, and media outlets to assault demographic clusters reconstructed as a "public" in numerical form. If money is the symbolic marker of who counts, the flow of cash to media and consulting organizations announced the lopsided victory of textual elites over the electorate. Candidates spent more than one billion dollars on political advertising, little of which found its way to ordinary citizens. No campaign finance reform proposal suggested free drinks or token payments for voters who took the trouble to trek to the polls to perform an abstract civic duty.

In conclusion, it may be said that modern presidential politics is a struggle among textual elites for control of a central political ritual in which popular bodies find little purchase. Neither advertised politics nor high-minded deliberation offers much celebration, broad-based invitation, or fun. Neither is fertile or spacious enough to constitute a broadly popular political life. This is regrettable, since elections are about more than choosing a mass-circulated presidential personality or piously discussing issues. They are also rites of solidarity in which participants may revel in popular power for its own sake. Progressive Era purification and textualization of campaign rituals commenced a long era of bodily disengagement from presidential elections in the US. Though reformers hoped to banish congregational crowds that did not share their more refined civic sensibilities, the bodily mass communication and public sensationalism they purged remain unique forms of political communication whose social bonds and collective messages are duplicated by no other means than live assembly.

It remains to ask what lessons can be drawn from this legacy of distrust for the forms of political expression and challenge that congregational crowds offer. Faced with continuing civic disengagement in the US, a number of voices have begun to argue for the democratic value of a physically celebratory politics. ${ }^{84}$ Does this mean that people should vote ignorant, drunk, and disorderly? What should be the role of political crowds in the twenty-first century? Are bullyboys ever a legitimate expression of political partisanship?

Though nineteenth-century election rituals were not uniformly inclusive and tolerated abuses that would no longer be acceptable, they remain democratically instructive. Live public sensations created broad points of entry into civic life, socialized the young, and appealed to less refined political dispositions. They suffused common space with uncommon sensations jointly shared. Popular social movements have drawn upon these aspects of crowd-based ritual ever since, often with powerful results. But crowds always remain unpredictable, and their potential for disturbance remains. It should, since the mere textualization of civic life is no guarantee of democracy. While crowds may be antidemocratic on some occasions, on others they may be all the democracy there is.

The line that congregational crowds ought to toe is not a theoretical but a historical question to be worked out in the press of political give and take. Bodily mass communication and public sensationalism have their democratic uses, even in excessive and impolite forms. History shows clearly that not only bodily groups move in herds. It is sometimes forgotten that in Germany in 1932, not just partisan intimidation but voting was part of the strategy by which Hitler's regime established itself. Observers have not, as a result, concluded that voting is too risky for the democratic process. Deliberative reasoning is not without its herd aspects, and the genteelly literate may be less discriminating than they seem. Critical consciousness is nurtured not only in literate communication or 
turn-taking discussion but also in collective bodily experience. We need involved and informed voters alike. These will rarely, and need not, be equally developed aspects in every elector. Rooting for the home team with all the romance and drama of the ballfield leads fans to be interested not only in baseball scores and histories, but also in team strategies, strengths, and weaknesses. We should trust political spectacle that much.

Congregational crowds contribute to a richer, more vital and responsive civic life. They are arenas of social fertility and political action. They create shared feelings of legitimacy in nations that call themselves democracies and count themselves as ideologically committed to the "people." Democratic publics can take stock of themselves only by gathering indiscriminately together. This is what electoral crowds offer. In the ritual proximity of popular assembly, citizens may combine in politically new and creative ways, encounter those with whom they share the world, and animate their aspirations with the force of live congregational experience.

Notes

[1] Peter Stallybrass and Allon White, Politics and Poetics of Transgression (Ithaca, NY: Cornell University Press, 1986).

[2] Robert Putnam, Bowling Alone (New York: Simon \& Schuster, 2000), 22-24.

[3] An exception to this is Susan G. Davis's study, Parades and Power: Street Theatre in NineteenthCentury Philadelphia (Berkeley: University of California Press, 1988).

[4] Daniel Dayan and Elihu Katz, Media Events: The Live Broadcasting of History (Cambridge, MA: Harvard University Press, 1992); Kurt Lang \& Gladys Engle Lang, "The Unique Perspective of Television," American Sociological Review 18 (1953): 3-12.

[5] Émile Durkheim, The Elementary Forms of Religious Life, trans. by K. A. Fields (New York: Free Press, 1995), 353.

[6] Jaap van Ginneken, Crowds, Psychology, and Politics, 1871-1899 (New York: Cambridge, 1992), 7884, 130-7, 171-87, 217-22, 226-30. See also J. S. McClelland, The Crowd and the Mob: From Plato to Canetti (Boston: Unwin Hyman, 1989), 155ff.

[7] See, for example, Charles Cooley, Social Organization: A Study of the Larger Mind (New York: Charles Scribner's Sons, 1909).

[8] Carolyn Marvin and David Ingle, Blood Sacrifice and the Nation: Totem Rituals and the American Flag (Cambridge: Cambridge University Press, 1999), 42ff; Carolyn Marvin, "The Body of the Text: Literacy's Corporeal Constant," Quarterly Journal of Speech 80 (1994): 129-49; See also John Kasson, Rudeness and Civility: Manners in Nineteenth-Century Urban America (New York: Hill \& Wang, 1990); Lawrence Levine, Highbrow/Lowbrow: The Emergence of Cultural Hierarchy in America (Cambridge, MA: Harvard University Press, 1988).

[9] For example, Jean Baker, "The Ceremonies of Politics: Nineteenth-Century Rituals of National Affirmation," in A Master's Due: Essays in Honor of David Herbert Donald, ed. W. J. Cooper, Jr. (Baton Rouge: Louisiana State University Press, 1985), 161-78; Michael McGerr, The Decline of Popular Politics: The American North, 1865-1928 (Oxford: Oxford University Press, 1986); Glen Altschuler and Stuart 
Blumin, Rude Republic: Americans and Their Politics in the Nineteenth Century (Princeton: Princeton University Press, 2000); and Michael Schudson, The Good Citizen: A History of American Civic Life (Cambridge, MA: Harvard University Press, 1998).

[10] Alexander Keyysar, The Right to Vote: The Contested History of Democracy in the United States (New York: Basic, 2000).

[11] Paul Kleppner, Who Voted? The Dynamics of Electoral Turnout (New York: Praeger, 1982), 34-37; McGerr, 5-7; Mark Kornbluh, Why America Stopped Voting: The Decline of Participatory Democracy and the Emergence of Modern American Politics (New York: New York University Press, 2000), 12-20.

[12] Chilton Williamson, American Suffrage from Property to Democracy, 1760-1860 (Princeton: Princeton University Press, 1962); Linda Kerber, "The Meanings of Citizenship," Journal of American History 83 (1997): 833-54.

[13] Kleppner, 34-39, 63-70, 123-24.

[14] John Nerone, Violence Against the Press: Policing the Public Sphere in U.S. History (New York: Oxford University Press, 1994).

[15] Paul Edwards, Strikes in the United States, 1881-1974 (New York: St. Martin's, 1981); Paul Gilje, Rioting in America (Bloomington: Indiana University Press, 1996), 116-23.

[16] Jean Baker, Affairs of Party: The Political Culture of Northern Democrats in the Mid-nineteenth Century (New York: Fordham University Press, 1998), 281-87.

[17] William Gienapp, “'Politics Seem to Enter Into Everything': Political Culture in the North, 18401860," in Essays on American Antebellum Politics, ed. S. E. Maizlish and J. J. Kushma (College Station: TexasA\&MUniversity Press, 1982), 32-35; Jean Baker, "Ceremonies of Politics," 161-76 and Affairs of Party, 291-304; McGerr, 22-41; Altschuler \& Blumin, 57-69.

[18] Paula Baker, "The Culture of Politics in the Late Nineteenth Century: Community and Political Behavior in Rural New York," Journal of Social History (1984), 180 and The Moral Frameworks of Public Life: Gender, Politics, and the State in Rural New York, 1870-1930 (New York: Oxford University Press, 1991), 39f; John Francis Reynolds, Testing Democracy: Election Behavior and Progressive Reform in New Jersey, 1880-1920 (Chapel Hill: University of North Carolina Press, 1988), 15-17; Jean Baker, Affairs of Party, 305-16.

[19] Elizabeth Varon, "Tippecanoe and the Ladies, Too: White Women and Party Politics in Antebellum Virginia," Journal of American History 82 (1995): 494-521; Elizabeth Varon, We Mean to be Counted: White Women and Politics in Antebellum Virginia (Chapel Hill: University of North Carolina Press, 1998), ch. 3; Robert Dinkin, Before Equal Suffrage: Women in Partisan Politics from Colonial Times to 1920 (Westport, CT: Greenwood, 1995), 31f; Rebecca Edwards, Angels in the Machinery: Gender in American Party Politics from the Civil War to the Progressive Era (New York: Oxford University Press, 1997), 14-15; see also Ronald Zboray and Mary Zboray, "Gender Slurs in Boston's Partisan Press During the 1840s," Journal of American Studies 34 (2000): 413-46.

[20] Varon, "Tippecanoe" Dinkin; David Grimsted, American Mobbing, 1828-1861: Toward Civil War (New York: Oxford University Press, 1998), 188; Mary Ryan, Women in Public: Between Banners and 
Ballots, 1825-1880. (Baltimore: Johns Hopkins University Press, 1990) and Civic Wars: Democracy and Public Life in the American City During the Nineteenth Century (Berkeley: University of California Press, 1997).

[21] McGerr, 28, 208.

[22] Dinkin, 77.

[23] McGerr, 24-26.

[24] Reynolds, Testing Democracy: Election Behavior and Progressive Reform in New Jersey, 1880-1920, 35.

[25] Kornbluh, 27-28.

[26] Roy Rappaport, Ritual and Religion in the Making of Humanity (Cambridge: Cambridge University Press, 1999), 119.

[27] Durkheim, 352.

[28] Jurgen Habermas, The Structural Transformation of the Public Sphere: An Inquiry into a Category of Bourgeois Society, trans. Thomas Burger (Cambridge, MA: MIT Press, 1991), 8-14.

[29] Levine.

[30] Quoted in Richard Jensen, The Winning of the Midwest: Social and Political Conflict, 1888-1896 (Chicago: University of Chicago Press, 1971), 37.

[31] Reynolds, 34-36; Grimsted, 181-87; Altschuler and Blumin, 69f.

[32] Quoted in Grimsted, 185.

[33] Quoted in Jean Baker, Affairs of Party, 277.

[34] Quoted in Grimsted, 182.

[35] Grimsted, 185-86.

[36] Quoted in Gienapp, 46-47.

[37] Quoted in Grimsted, 186.

[38] Reynolds, 16, 35.

[39] Quoted in Grimsted, 198; see also 181-98.

[40] Allen Thorndike Rice, "Recent Reforms in Balloting," North American Review 143 (1886): 628-43.

[41] Grimsted; see also Michael Feldberg, The Turbulent Era: Riot and Disorder in Jacksonian America (Oxford: Oxford University Press, 1980), 55-61; Nerone, Violence Against the Press: Policing the Public Sphere in U.S. History, 81; and Gilje, 130-31, passim. 
[42] Richard Jensen, "Armies, Admen, and Crusaders: Types of Presidential Election Campaigns," History Teacher 2 (1969): pp. 33-50; Jean Baker, "Ceremonies of Politics," and Affairs of Party, 287-301;

McGerr, 24-26.

[43] Williamson; Lionel E. Fredman, The Australian Ballot: The Story of an American Reform (Lansing: Michigan State University Press, 1968); Jean Baker, Affairs of Party, 306-8.

[44] Spencer Albright, The American Ballot (Washington, DC: American Council on Learned Affairs, 1942).

[45] See Paul Bourke and Donald DeBats, "Identifiable Voting in Nineteenth-century America: Toward a Comparison of Britain and the United States Before the Secret Ballot," Perspectives in American History 11 (1977-78): 259-90.

[46] Henry George, "Money in Elections," North American Review 136 (1883): 201-12; Grimsted, 19496; Altschuler and Blumin, 72-75.

[47] Jensen, Winning of the Midwest, 40f.

[48] Reynolds, 54-56.

[49] Altschuler and Blumin, 70-72.

[50] Altschuler and Blumin, 82.

[51] See Kenneth Cmiel, Democratic Eloquence: The Fight Over Popular Speech in 19th-Century America (New York: William Morrow, 1990), 66-74, 139-44, 191-204; and Richard Bushman, The Refinement of America: Persons, Houses, Cities (New York: Knopf, 1992).

[52] Quoted in Reynolds, 57.

[53] Joseph Harris, "The Progress of Permanent Registration of Voters," The American Political Science Review 23, issue 4 (1929): 908-14; Frances Piven and Richard Cloward, Why Americans Still Don't Vote (New York: Pantheon, 2000).

[54] Comer Vann Woodward, The Strange Career of Jim Crow (New York: Oxford University Press, 1974).

[55] Leon Aylsworth, "The Passing of Alien Suffrage," The American Political Science Review 25 (1931): 114-6.

[56] Arthur Link and Richard McCormick, Progressivism (Arlington Heights, IL: Harlan Davidson, 1983).

[57] Quoted in Reynolds, 122. See also Kornbluh, 130-34.

[58] Fredman, IX.

[59] Quoted in Albright, 26.

[60] Reynolds, 63.

[61] Reynolds, 115-17, 123-24.

[62] Quoted in Reynolds, 114. 
[63] Quoted in Kornbluh, 113; McGerr, 100.

[64] Quoted in Kornbluh, 5-7.

[65] Quoted in Kornbluh, 145-51.

[66] McGerr.

[67] Quoted in Reynolds, 94.

[68] Jensen, “Armies, Admen” McGerr.

[69] Jensen, Winning of the Midwest, 165-77; McGerr, 69-106; Edwards, 86ff.

[70] Quoted in Michael McGerr, 98.

[71] McGerr, 121.

[72] Jensen, "Armies, Admen," and Winning of the Midwest, 165-77; Robert Westbrook, "Politics as Consumption: Managing the Modern American Election," in The Culture of Consumption: Critical Essays in American History, 1880-1980, ed. T. J. Jackson Lears (New York: Pantheon, 1983), 143-73; McGerr, ch. 6.

[73] McGerr, 140, 173.

[74] Quoted in McGerr, 145.

[75] McGerr, "Political Style and Women's Power, 1830-1930."

[76] Linda Greenhouse, "U.S. Civil Rights Commission Report Finds African-American Ballots Were at Disadvantage in Florida," New York Times, 14 June 2001, A11.

[77] Gail Collins, “Call it a Tie," New York Times, 10 November 2000, A33.

[78] Quoted in David E. Sanger, "Momentous Challenges as Bush Reaches for 12 Minutes of Inaugural Fame," New York Times, 20 January 2001, A16.

[79] Evelyn Nieves, "Portland Shrugs Off a Turn in the Spotlight," New York Times, 2 November 2000, A29.

[80] Daniel Asimov, “Presidential Debates,” New York Times, 16 September 2000, A14.

[81] Excerpts from debate, in which Bush and Gore clashed on Medicare. New York Times,4 October 2000, A29.

[82] Excerpt from the third Presidential Debate between Bush and Gore. New York Times, 18 October 2000, A26.

[83] Peter Marks, "To Some Complaints, Focus Groups Emerge as Stars of the Fall Season," New York Times, 19 October 2000, A28.

[84] See, for example, Robert Ivie, Rhetorical Deliberation and Democratic Politics in the Here and Now," Rhetoric and Public Affairs 5.2 (2002): 277-85; Theda Skocpol, Diminished Democracy: From

Membership to Management in American Civic Life (Norman: University of Oklahoma Press, 2002); 
Thomas E. Patterson, Vanishing Voter: Public Involvement in an Age of Uncertainty (New York: Knopf, 2002).x 